\title{
Changes in Expression of Platelet-Derived Growth Factor and Its Receptors in the Lungs of Newborn Rats Exposed to Air or $60 \% \mathrm{O}_{2}$
}

\author{
SHILPA BUCH, ROBIN N. N. HAN, JUDY CABACUNGAN, JINXIA WANG, SHIZENG YUAN, \\ ROSETTA BELCASTRO, JULIE DEIMLING, ROBERT JANKOV, XIAOPING LUO, \\ STEPHEN J. LYE, MARTIN POST, AND A. KEITH TANSWELL
}

Medical Research Council Groups in Lung Development [R.B., S.B., J.C., J.D., R.N.N.H., R.J., X.L., M.P., A.K.T., J.W., S.Y.] and Development and Fetal Health [S.J.L.], Lung Biology Programme, Hospital for

Sick Children Research Institute, Samuel Lunenfeld Research Institute, Mt. Sinai Hospital, and the Departments of Obstetrics, Paediatrics, and Physiology, University of Toronto, Toronto, Ontario, Canada

\begin{abstract}
PDGF-related gene expression has been well characterized during fetal rat lung development and adult rat lung injury, but not during normal postnatal lung growth or injury. Lung expression of the mRNA for PDGF-A, $-\mathrm{B},-\alpha \mathrm{R}$, and $-\beta \mathrm{R}$ and immunoreactive PDGF-AA, $-\mathrm{BB},-\alpha \mathrm{R}$, and $-\beta \mathrm{R}$ were assessed in rat pups raised in air or $60 \% \mathrm{O}_{2}$ for up to $14 \mathrm{~d}$ after birth. Expression of mRNA and immunoreactive ligand did not correlate for pups raised in air. Immunoreactive PDGF- $\alpha \mathrm{R}$ and $-\beta \mathrm{R}$, but not PDGF-AA and -BB, were evident throughout the lung at birth. Both PDGF-AA and -BB were evident in airway epithelium, PDGF-BB in alveolar epithelial cells and PDGF-AA was widely distributed in parenchymal tissue at $4 \mathrm{~d}$. PDGF- $\alpha \mathrm{R}$ was localized to airway epithelium, and PDGF- $\beta$ R to subendothelial perivascular regions and to airway and alveolar epithelium at $4 \mathrm{~d}$. Immunoreactive PDGF ligands all declined after $4 \mathrm{~d}$. Intraperitoneal injection of neutralizing antibodies or truncated soluble receptors to PDGF-BB reduced lung DNA synthesis in air.
\end{abstract}

\section{ABSTRACT}

Exposure to $60 \% \mathrm{O}_{2}$ significantly increased mRNA for PDGF-B, $-\beta \mathrm{R}$, and $-\alpha \mathrm{R}$, but not PDGF-A, relative to air-exposed lung at various time points after birth. PDGF-A, $-\mathrm{B}$, and $-\alpha \mathrm{R}$ immunoreactivities in these lungs were reduced and delayed, consistent with a global inhibition of lung growth. Pups exposed to $60 \% \mathrm{O}_{2}$ had a similar distribution of PDGF- $\beta$ R to that seen in air, except that at $14 \mathrm{~d}$ PDGF- $\beta \mathrm{R}$ was distributed throughout the lung parenchyma. We conclude that PDGF ligands and receptors are important for normal postnatal lung growth and that their expression is delayed by $\mathrm{O}_{2}$ exposure. (Pediatr Res 48: 423-433, 2000)

\[ \text { Abbreviations } \]
BPD, bronchopulmonary dysplasia
IGF-IR, type I IGF receptor
PDGF, platelet-derived growth factor
PDGF-R, platelet-derived growth factor receptor

Sustained inhalation of supraphysiological concentrations of oxygen $\left(\mathrm{O}_{2}\right)$ is an obligatory therapeutic intervention for many clinical situations presenting with systemic hypoxemia. Despite attempts to maintain arterial $\mathrm{O}_{2}$ concentrations in the normal range, this use of $\mathrm{O}_{2}$ may be accompanied by tissue damage, in particular to the lung, which receives direct exposure (1). BPD, a chronic pneumopathy occurring primarily in

Received February 10, 2000; accepted June 1, 2000.

Correspondence: Dr. Keith Tanswell, Division of Neonatology, Hospital for Sick Children, 555 University Avenue, Toronto, Ontario, Canada, M5G 1 X8.

Supported by group grants (S.B., S.J.L., M..P, A.K.T.) from the Medical Research Council of Canada, and an equipment grant from the Ontario Thoracic Society. A.K.T. holds the Hospital for Sick Children Women's Auxiliary and University of Toronto Chair in Neonatal Medicine. premature infants requiring prolonged respiratory support, has long been recognized to result, at least in part, from pulmonary oxygen toxicity (2). An understanding of the molecular and cellular events leading to the histopathological changes observed with BPD was, for many years, hampered by the lack of appropriate neonatal animal models (3), and our understanding of the mediators of pulmonary $\mathrm{O}_{2}$ toxicity was dependent on studies in adult animals. We, and others, have used adult rat models to correlate $\mathrm{O}_{2}$-mediated pulmonary cellular hyperplasias to changes in expression of various growth factor genes (4-7). Such models offer simplicity, in that the adult lung is essentially a nonproliferative organ that may be expected to have major alterations in growth factor expression following the onset of a proliferative lung injury. In contrast, the neonatal 
lung is normally a proliferative organ, even in the absence of injury. BPD is characterized by a net reduction of overall lung growth, as assessed by late morphometric analysis (8) and histologic observations of autopsy material (9). Superimposed on this overall effect, there is a continued division of specific cell types, such as pneumocytes during repair of the alveolar epithelium, perivascular smooth muscle with the development of pulmonary hypertension, and interstitial fibroblasts with the development of pulmonary fibrosis.

Recently, animal models of neonatal lung injury that have pathologic characteristics of BPD have been described, including the baboon (10), rat $(11,12)$, and mouse (13). As previously reported (11), the newborn rat subjected to a continuous 14-d exposure to $60 \% \mathrm{O}_{2}$ has an overall reduction in lung growth, while retaining patchy areas of parenchymal thickening and active DNA synthesis. These histologic changes were accompanied by a reduced lung volume and elastance (11). Patchy foci of cellular hyperplasia, observed with $\mathrm{O}_{2}$ toxicity and a variety of other lung injuries, are believed to be mediated through polypeptide growth factors $(14,15)$, and altered expression of IGF-I and its type I receptor, IGF-IR, was seen in the neonatal rat model of pulmonary oxygen toxicity (11).

Both homodimers of PDGF (PDGF-AA and PDGF-BB) appear to play critical roles in early lung organogenesis. PDGF-AA is required for branching, and PDGF-BB for the parallel increase in lung mass seen during the branching process (16). In other studies, we have demonstrated positive PDGF-BB immunoreactivity in the epithelial cells of the developing airways and peripheral lung at the late canalicular stage of fetal rat lung development (d 20 of 22), which then declines before birth (17). We have also documented the responsiveness of fetal and neonatal lung epithelial cells to exogenous PDGF-BB in vitro (18-20). Based on these studies, we hypothesized that expression of PDGF-related genes would be up-regulated following birth, possibly as a mediator of pneumocyte hyperplasia occurring during normal postnatal alveolarization. Based on our previous observations with IGF-I and IGF-IR, we anticipated that exposure of newborn rats to $60 \% \mathrm{O}_{2}$ would down-regulate expression of whole lung PDGFrelated mRNA, but that increased PDGF ligand and receptor would be found in areas of parenchymal thickening, which we have previously shown to be sites of residual active DNA synthesis (11).

\section{METHODS}

Materials. Radioisotopes were from ICN Radiochemicals (Irvine, CA, U.S.A.), nylon membrane from Amersham Canada (Oakville, Ontario, Canada) and restriction enzymes and dextran sulfate from Pharmacia (Baie D'Urfé, Québec, Canada). BSA type V, Ficoll 400, polyvinylpyrrolidone, guanidinium thiocyanate, cesium chloride, and salmon sperm DNA were from Sigma Chemical Co. (St. Louis, MO, U.S.A.). Organic solvents were of HPLC grade. Rabbit anti-human PDGF-BB and -AA polyclonal IgG for immunohistochemistry, a goat-neutralizing anti-human PDGF-BB IgG and nonspecific goat and rabbit IgG were from Genzyme (Boston, MA, U.S.A.). Rabbit anti-human PDGF $\beta$-receptor polyclonal IgG was from UBI (Lake Placid, NY, U.S.A.). Goat anti-mouse IgG and a rabbit anti-human PDGF $\alpha$-receptor polyclonal IgG were from Santa Cruz Biotechnology (Santa Cruz, CA, U.S.A.). A mouse MAb to $\alpha$-smooth muscle actin was from Lab Vision (Freemont, CA, U.S.A.). Rabbit peroxidase/antiperoxidase soluble immune complex (PAP) and a FITCconjugated rabbit anti-goat IgG were from ICN Immuno Biologicals (Costa Mesa, CA, U.S.A.). A kit for avidin-biotin peroxidase complex immunocytochemical staining was from Vector Laboratories (Burlingame, CA, U.S.A.), and $\alpha$-aminopropyl-triethoxysilane from Pierce Chemical Company (Rockford, IL, U.S.A.). Nitrocellulose membrane was from Schleicher and Schuell (Keene, NH, U.S.A.). A cDNA for $18 \mathrm{~S}$ ribosomal RNA was a gift from Dr. D. Denhardt (Rutgers University, Piscataway, NJ, U.S.A.). DNAzol ${ }^{\circledR}$-genomic DNA isolation reagent was from Molecular Research Center (Cincinnati, OH, U.S.A.). DEPC (diethylpyrocarbonate) was from ICN Biomedicals (Aurora, OH, U.S.A.). PDGF-R $\beta / \mathrm{Fc}$ chimera, a soluble truncated receptor for PDGF-BB, was purchased from R\&D Systems (Minneapolis, MN, U.S.A.).

Institutional review. All procedures involving animals were conducted according to criteria established by the Canadian Council for Animal Care, and prior approval was obtained from the Animal Care Review Committee at the Samuel Lunenfeld Research Institute, Mt. Sinai Hospital.

Exposure system. Pathogen-free timed pregnant Sprague Dawley rats (250-275 g) were obtained from Charles River (St. Constant, Québec, Canada). All experiments were conducted as paired exposures with one chamber receiving $60 \%$ $\mathrm{O}_{2}$ and the other receiving air. On the anticipated day of delivery each animal was placed in a $60 \times 48 \times 25 \mathrm{~cm}$ plastic chamber with $12 \mathrm{~h}: 12 \mathrm{~h}$ light-dark cycles. Food and water were available ad libitum. Chambers were connected to an air or $\mathrm{O}_{2}$ source before placing animals in the chambers and delivery occurred in the selected gas. Oxygen concentrations were calibrated daily using an online SensorMedics $\mathrm{O}_{2}$ analyzer (Summit Technologies, Oakville, Ontario, Canada). Gas flow was adjusted to maintain minimal chamber humidity with a $\mathrm{CO}_{2}$ concentration below $0.5 \%$ using an online SensorMedics $\mathrm{CO}_{2}$ analyzer (Summit Technologies). Dams were exchanged daily between $\mathrm{O}_{2}$ and air chambers to prevent maternal $\mathrm{O}_{2}$ toxicity. The number of pups in each paired litter was adjusted to $10-12$ pups at the onset of the exposure period. Balanced litter sizes were maintained by removing an equal number of pups from air-exposure chambers as died in paired $\mathrm{O}_{2}$ chambers. The mortality rate after $14 \mathrm{~d}$ in $60 \% \mathrm{O}_{2}$ was $<20 \%$ (11).

Isolation of lung RNA. A total of 36 litters were used, with 4 litters at each time point for each gas. All lungs from each litter were pooled for isolation of total lung RNA. The thoracic contents were removed en bloc and the lungs dissected away from vessels and large airways, to be flash frozen in liquid nitrogen after weighing. Total (nuclear and cytoplasmic) RNA was isolated by lysing the tissue in $4 \mathrm{M}$ guanidinium thiocy-

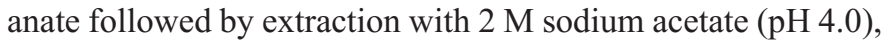
phenol, and chloroform/isoamyl alcohol (21). RNA was isopropanol precipitated and collected by centrifugation. This RNA was dried under vacuum and dissolved in DEPC-treated water. Integrity of RNA was assessed from the visual appear- 
ance of the ethidium bromide-stained ribosomal bands following fractionation on a $1.2 \%(\mathrm{wt} / \mathrm{vol})$ agarose-formaldehyde gel.

PCR-generated molecular probes. Total RNA was isolated and RT-PCR was performed as described previously (22). The amplified PCR products were then gel purified and ligated into PCR II (In Vitrogen, San Diego, CA, U.S.A.) with T4 DNA ligase. After transformation of competent Escherichia coli, several colonies were picked for sequence analysis using the dideoxy chain termination method according to the manufacturer's instructions (Pharmacia). Sequence analysis showed a greater than $95 \%$ homology to the published sequence. The primers chosen for PDGF-A chain, 5'-CACGGGGTCCATGCCACTAAGCAT-3' and 5'-ATCCGGATTCTGGCTTGTGGTCGC-3', were based on the human genomic sequence (23), giving a $366 \mathrm{bp}$ fragment. The primers for the PDGF-B chain, 5'-AGTCGGCATGAATCGCTGCTGGG-3' and 5'TTTCTCACCTGGACCGGCCGCAT-3', were based on the murine genomic sequence (24) and when amplified gave a fragment of $476 \mathrm{bp}$. The primers for the PDGF $\alpha$-receptor, 5'-ATTGTGCCGCTGAGTTCGTCC-3' and 5'-GGCATAAACGTTAAACTCGCTGG-3', were based on the rat cDNA sequence (Genbank \#: RNDPDGFACE) giving an amplified fragment of $488 \mathrm{bp}$. The primers for the PDGF $\beta$-receptor, $5^{\prime}$-CGACGATTCCATGCCGAGTGACA-3' and 5'-AGTGGACAGAACCAACTCGCC-3', were based on a rat cDNA sequence (Genbank \#: RNDPDGRRBE), giving a $654 \mathrm{bp}$ fragment. The RT-PCR-generated cDNA were excised from PCR II plasmids by restriction digestion, labeled with $\left[\alpha^{32} \mathrm{P}\right] \mathrm{dCTP}$ by random hexamer priming, and used as hybridization probes.

Northern blot analyses. All Northern blot analyses were performed using $20 \mu \mathrm{g}$ of RNA. The total RNA samples from lungs exposed to air or to $60 \% \mathrm{O}_{2}$ were denatured in a loading buffer containing $2.2 \mathrm{M}$ formaldehyde for $5 \mathrm{~min}$ at $65^{\circ} \mathrm{C}$ and electrophoresed in $1 \%(\mathrm{wt} / \mathrm{vol})$ agarose gels containing $0.66 \mathrm{M}$ formaldehyde. The RNAs were transferred to Hybond- $\mathrm{N}^{+}$ nylon membrane (Amersham, Arlington Heights, IL, U.S.A.) using the capillary transfer technique. After transfer the blots were air dried and fixed in a UV crosslinker (Stratagene, La Jolla, CA, U.S.A.). All probes were labeled with deoxycytidine $5^{\prime}-\left[\alpha{ }^{32} \mathrm{P}\right]$ triphosphate by a random-primed labeling system (Amersham), with specific activities of $0.5-2.9 \times 10^{9}$ counts/ $\mathrm{min} / \mu \mathrm{g}$ DNA. Prehybridization $(\geq 2 \mathrm{~h})$ and hybridizations (overnight) were performed in $50 \%$ (vol/vol) formamide; $5 \times$ SSPE $[=750 \mathrm{mM} \mathrm{NaCl} ; 50 \mathrm{mM}$ sodium phosphate, $5 \mathrm{mM}$ EDTA, pH 7.4]; $5 \times$ Denhardt's solution $[=0.1 \%(\mathrm{wt} / \mathrm{vol})$ each of BSA, Ficoll, and polyvinylpyrrolidone]; $0.5 \%$ (wt/vol) SDS; $100 \mu \mathrm{g} / \mathrm{mL}$ denatured sheared salmon sperm DNA at $42^{\circ} \mathrm{C}$. After hybridization, the blots were washed in $2 \times \mathrm{SSC}$ [ $=300 \mathrm{mM} \mathrm{NaCl}, 30 \mathrm{mM}$ sodium citrate, $\mathrm{pH} 7.0], 0.1 \% \mathrm{SDS}$ at room temperature for $10 \mathrm{~min}$, and a second time in the same stringency at $42^{\circ} \mathrm{C}$ for $5-10 \mathrm{~min}$. Most of any residual nonspecific binding, particularly with the probe for PDGF-A, was removed by a quick additional wash in $1 \times \mathrm{SSC}, 0.2 \%(\mathrm{wt} / \mathrm{vol})$ SDS at $42^{\circ} \mathrm{C}$ for $2-5 \mathrm{~min}$. The blots were exposed for $4 \mathrm{~d}$ for PDGF-A, $1 \mathrm{~h}$ for $18 \mathrm{~S}$ rRNA, and otherwise for $24-48 \mathrm{~h}$, to Kodak XAR-5 film using Dupont Cronex intensifying screens.
The films were quantified by an Ultroscan XL laser densitometer (LKB, Bromma, Sweden).

Glyceraldehyde 3'-phosphate dehydrogenase (GAPD; EC 1.2.1.12) and $\beta$-actin probes are commonly used as controls, but in studies of $\mathrm{O}_{2}$-mediated alterations of gene expression they cannot be used as the expression of both actin (25) and GAPD (data not shown) mRNA are affected by exposure to elevated concentrations of $\mathrm{O}_{2}$. To correct for variations in loading of gels and transfer to membranes, all results were normalized to the $18 \mathrm{~S}$ ribosomal RNA, as previously described for studies of IGF mRNA in this model (11).

Synthesis of nonradioactive riboprobes. Plasmids containing PDGF-A and PDGF-B cDNA probe inserts were linearized using the appropriate restriction endonuclease. The linear plasmid was then separated from uncut plasmid on a $1.5 \%$ (wt/vol) Tris-borate-EDTA agarose gel and subsequently isolated from the gel using a gel extraction kit (Qiagen, Mississauga, Ontario, Canada). Single-stranded sense and antisense digoxigenin (DIG)-labeled riboprobes were then synthesized by in vitro transcription, using the DIG RNA Labeling Kit from Boehringer Mannheim (Indianapolis, IN, U.S.A.). The labeled riboprobes were then ethanol-precipitated and resuspended in DEPC-treated water.

In situ hybridization. Tissue sections in paraffin were dewaxed in xylene for $20 \mathrm{~min}$, then rehydrated in a decreasing ethanol series and washed in PBS. The sections were then fixed in $4 \%(\mathrm{wt} / \mathrm{vol})$ paraformaldehyde for $20 \mathrm{~min}$ and washed in PBS. Tissue permeabilization was achieved by treating the sections with $20 \mu \mathrm{g} / \mathrm{mL}$ of proteinase $\mathrm{K}$ in $50 \mathrm{mM}$ Tris $(\mathrm{pH}$ 8.0), $5 \mathrm{mM}$ EDTA for $17 \mathrm{~min}$ at $20^{\circ} \mathrm{C}$. Tissue sections were then washed in PBS and fixed in 4\% (wt/vol) paraformaldehyde for $5 \mathrm{~min}$. After rinsing with DEPC-treated water, slides were washed in $0.1 \mathrm{M}$ triethanolamine, $0.25 \%$ (vol $/ \mathrm{vol}$ ) acetic anhydride for $10 \mathrm{~min}$ at $20^{\circ} \mathrm{C}$, washed in PBS and dehydrated through an ascending ethanol series before being air-dried for the addition of the hybridization solution. DIG-labeled riboprobes $(\approx 1 \mathrm{ng} / \mu \mathrm{L})$ were added to freshly prepared hybridization solution $[50 \%(\mathrm{wt} / \mathrm{vol})$ deionized formamide, $10 \%(\mathrm{wt} /$ vol) dextran sulfate, $1.5 \times$ Denhardt's reagent, $0.5 \mathrm{mg} / \mathrm{mL}$ yeast tRNA, $0.3 \mathrm{M} \mathrm{NaCl}, 5 \mathrm{mM}$ EDTA, $25 \mathrm{mM}$ Tris; $\mathrm{pH}$ 7.6] and the mixture denatured at $95^{\circ} \mathrm{C}$ for $3 \mathrm{~min}$. The cooled hybridization solution was incubated with the slides in a humid chamber overnight at $55^{\circ} \mathrm{C}$. Sequential washes were: $5 \times \mathrm{SSC}$, $50 \%(\mathrm{vol} / \mathrm{vol})$ formamide for $1 \mathrm{~h}$ at $55^{\circ} \mathrm{C} ; 0.5 \mathrm{M} \mathrm{NaCl}, 10 \mathrm{mM}$ Tris, $5 \mathrm{mM}$ EDTA, $\mathrm{pH} 7.5$ for $15 \mathrm{~min}$ at $20^{\circ} \mathrm{C}$ then $\times 2$ for 10 $\min$ at $37^{\circ} \mathrm{C} ; 10 \mu \mathrm{g} / \mathrm{mL}$ RNAase $\mathrm{A}, 0.5 \mathrm{M} \mathrm{NaCl}, 10 \mathrm{mM}$ Tris, $5 \mathrm{mM}$ EDTA, pH 7.5 for $30 \mathrm{~min}$ at $37^{\circ} \mathrm{C} ; 0.5 \mathrm{M} \mathrm{NaCl}, 10 \mathrm{mM}$ Tris, $5 \mathrm{mM}$ EDTA, pH 7.5 for $15 \mathrm{~min}$ at $37^{\circ} \mathrm{C}$. These were followed by stringent washes in $2 \times \mathrm{SSC}$ and $0.1 \times \mathrm{SSC}$ at $50^{\circ} \mathrm{C}$. Slides were then incubated in $1 \%(\mathrm{wt} / \mathrm{vol})$ blocking solution, from a DIG-nucleic acid detection kit (Boehringer Mannheim), in $100 \mathrm{mM}$ maleic acid, $150 \mathrm{mM} \mathrm{NaCl}$, pH 7.7 for $1 \mathrm{~h}$ at $20^{\circ} \mathrm{C}$ to block nonspecific binding of the primary antibody against the DIG label. A 1:500 dilution of alkaline phosphatase-conjugated anti-DIG antibody, diluted in blocking buffer, was applied to the tissue sections for $1.5-2 \mathrm{~h}$ at $20^{\circ} \mathrm{C}$, following which they were washed $\times 2$ in $100 \mathrm{mM}$ maleic acid, $150 \mathrm{mM} \mathrm{NaCl}$, pH 7.5 for 15 min to remove unbound antibody. 
The $\mathrm{pH}$ of the sections was adjusted to 9.5 by washing in detection buffer $(0.1 \mathrm{M}$ Tris, $0.1 \mathrm{M} \mathrm{Na} \mathrm{Cl}, 50 \mathrm{mM} \mathrm{MgCl}, \mathrm{pH}$ 9.5). Color formation was initiated by the addition of 175 $\mu \mathrm{g} / \mathrm{mL}$ 5-bromo-4-chloro-3-indoyl phosphate and 337.5 $\mu \mathrm{g} / \mathrm{mL}$ nitroblue tetrazolium salt in detection buffer for $2 \mathrm{~h}$ in the dark. Color development was arrested by immersing the slides in distilled water. Lastly, the slides were counterstained with nuclear fast red before dehydration and mounting.

Immunohistochemistry. Animals were anesthetized with intraperitoneal ketamine $(80 \mathrm{mg} / \mathrm{kg})$ and xylazine $(20 \mathrm{mg} / \mathrm{kg})$. A tracheal catheter was inserted and sutured in place to facilitate lung inflation. The anterior part of the chest wall was reflected upward. While the heart was beating, a catheter was inserted through the right ventricle into the main pulmonary artery and an incision made in the left atrial appendage to allow drainage. The pulmonary circulation was then flushed with PBS containing $1 \mathrm{unit} / \mathrm{mL}$ heparin, during intermittent lung inflations, until the lung became white, then fixed with freshly prepared $4 \%(\mathrm{wt} / \mathrm{vol})$ paraformaldehyde and $0.02 \%(\mathrm{vol} / \mathrm{vol})$ glutaraldehyde by perfusion under a constant airway pressure of $10 \mathrm{~cm} \mathrm{H}_{2} \mathrm{O}$. The lungs were embedded in paraffin and cut in 5 - $\mu \mathrm{m}$ sections. Sections were mounted on $\alpha$-aminopropyltriethoxysilane-coated slides. After completion of immunohistochemical studies, using an avidin-biotin-peroxidase complex method (26), slides were lightly counterstained with Carazzi hematoxylin, dehydrated, cleared in xylene, and mounted. Dilutions of the primary antisera were 1:300 for PDGF- $\alpha$ R, $1: 1500$ for PDGF- $\beta$ R, 1:200 for PDGF-AA, 1:100 for PDGF$\mathrm{BB}$, and 1:1000 for $\alpha$-smooth muscle actin. Antibody specificity was verified by both omitting the primary antiserum or by replacing it with nonimmune rabbit IgG. The specificity of the antibodies has been previously confirmed by a lack of staining after the primary antisera had been immunoabsorbed with either recombinant human PDGF-AA or -BB (27), or PDGF- $\alpha \mathrm{R}$ and $-\beta \mathrm{R}$ blocking peptides (28). Animals selected for immunohistochemistry were chosen arbitrarily from the average-sized pups of each litter.

Interventions. Pups in air received intraperitoneal injections of $100 \mu \mathrm{g} / 50 \mu \mathrm{L}$ of either neutralizing goat anti-human PDGF-BB IgG in PBS or isotype-nonspecific IgG in PBS on d 4 and 5 of life. Because of limitations of injection volume, pups could not be studied at an earlier age. Four average-sized pups from a single litter were used in each group. In a separate experiment, four pups each were similarly injected with isotype-nonspecific $\operatorname{IgG}$ in PBS, or PBS alone, to exclude any nonspecific effects of IgG injection. On d 6, the pups received $1 \mu \mathrm{Ci} / \mathrm{gm}$ intraperitoneal $\left[{ }^{3} \mathrm{H}\right]$ thymidine $2 \mathrm{~h}$ before sacrifice. Genomic DNA in the lung tissue was isolated using DNAzol reagent (29). $\left[{ }^{3} \mathrm{H}\right]$ Thymidine incorporation into DNA was measured by scintillation counting of defined quantities of DNA, as measured by fluorospectrophotometry (30) using a Hitachi (Tokyo, Japan) F-2000 fluorescence spectrophotometer. Confirmation that goat anti-human PDGF-BB IgG reached the lung following intraperitoneal injection was obtained in two ways. Firstly, the presence of goat IgG in the lung was demonstrated by immunohistochemistry using FITC-conjugated rabbit anti-goat IgG (1:200), with control animals injected with nonspecific rabbit IgG. Secondly, rabbit anti- human PDGF-BB immunohistochemistry was used, as above, to demonstrate loss of PDGF-BB immunoreactivity following intraperitoneal injection of goat neutralizing antibody to PDGF-BB.

The PDGF-R $\beta / \mathrm{Fc}$ chimera soluble truncated receptor was injected i.p. [ $\approx 3 \mu \mathrm{g} / \mathrm{g}$ in $20 \mu \mathrm{L} 0.2 \%$ (wt/vol) BSA in PBS] on d 2 of life. This concentration was based on preliminary experiments to define maximal inhibitory effects (data not shown), and the reduced injection volume allowed the study of pups at an earlier age than had been possible using antibody interventions. $\left[{ }^{3} \mathrm{H}\right]$ Thymidine incorporation into DNA was measured on d 4 of life, as described above.

Data presentation. Unless otherwise stated, all numerical values are shown as mean \pm SEM of four litters for each time point. Statistical significance $(p<0.05)$ was determined by ANOVA followed by assessment of differences using Duncan's multiple range test (31). SE bars are not evident for all data points shown in the figures because they fall within the plot point.

\section{RESULTS}

Northern blot analyses of PDGF-B mRNA identified a single transcript of $3.5 \mathrm{~kb}$ (Fig. 1), consistent with previous observations in fetal rat lung (32). In air-exposed animals, the steady state expression of PDGF-B chain mRNA was only significantly different $(p<0.05)$ from expression at birth at $10 \mathrm{~d}$, at which time point it was reduced (Fig. 1). The steady state expression of PDGF-B chain mRNA in the lungs of the $60 \%$ $\mathrm{O}_{2}$-exposed animals was only significantly different $(p<0.05)$ from values at birth at $6 \mathrm{~d}$. However, there were significant
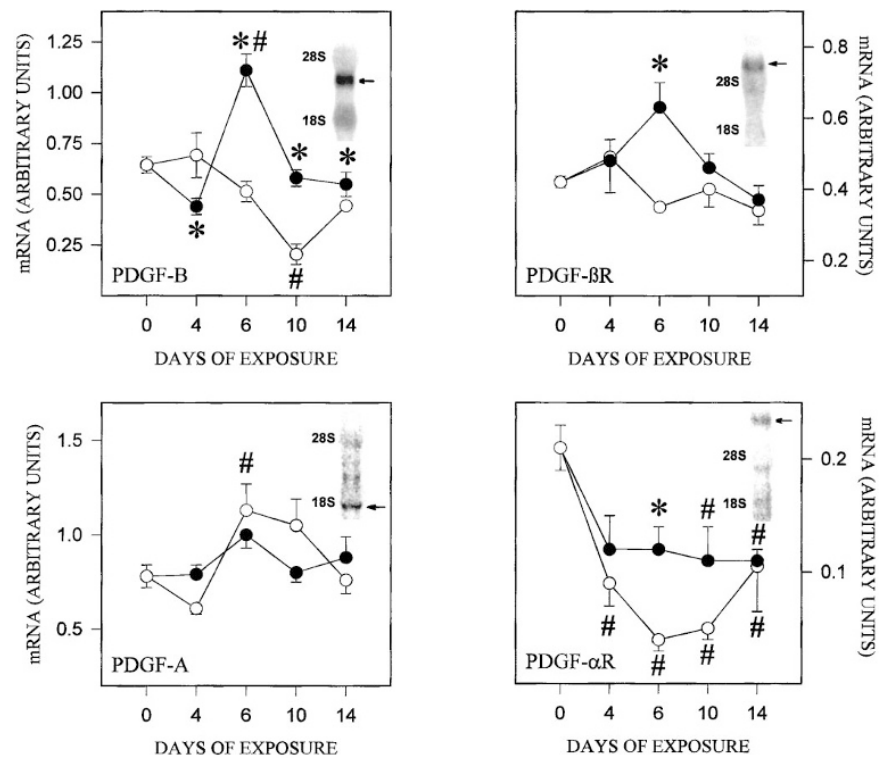

Figure 1. Steady state expression of mRNA from birth to $14 \mathrm{~d}$ of age, as assessed by Northern analyses, encoding the PDGF-A and -B chains, and the PDGF $-\alpha$ R and $-\beta$ R. Pups were exposed to air $(\bigcirc)$ or $60 \% \mathrm{O}_{2}(\bullet)$. Included in each panel is an example of a Northern blot to illustrate transcript sizes. The transcript sizes (arrows) for PDGF-A, PDGF-B, PDGF- $\alpha$ R, and PDGF- $\beta$ R were $1.7,3.5,6.5$, and $5.3 \mathrm{~kb}$, respectively All data points represent the mean \pm SEM for four litters. Where error bars are not evident they fall within the plot point. $\#=p<0.05 v s$ values at birth; $*=p<0.05 v s$ values in air on the same day. 


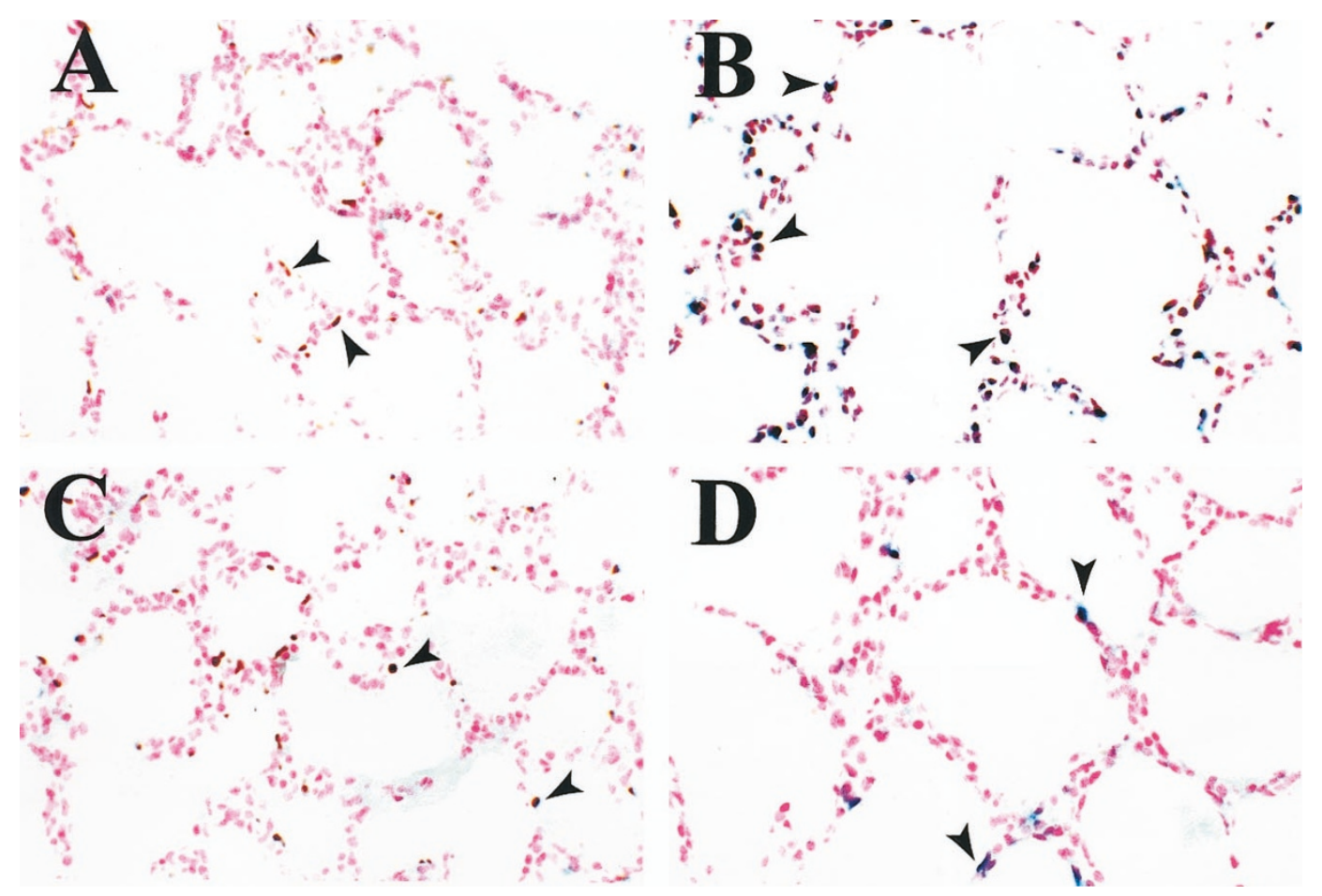

Figure 2. In situ hybridization for PDGF-B $(A, B)$ or PDGF-A $(C, D)$ mRNA in rat pups exposed to air $(A, C)$ or $60 \% \mathrm{O}_{2}(B, D)$ for 6 d. A minimal number of cells positive for PDGF-B $(A)$ or PDGF-A $(C)$ mRNA were evident (arrows) in air-exposed lungs. Lungs exposure to $60 \% \mathrm{O}_{2}$ had no obvious increase in the number of cells positive for PDGF-A mRNA (arrows), but had a marked increase in the number of cells positive for PDGF-B mRNA (arrows). Original magnification for all panels $\times 400$.
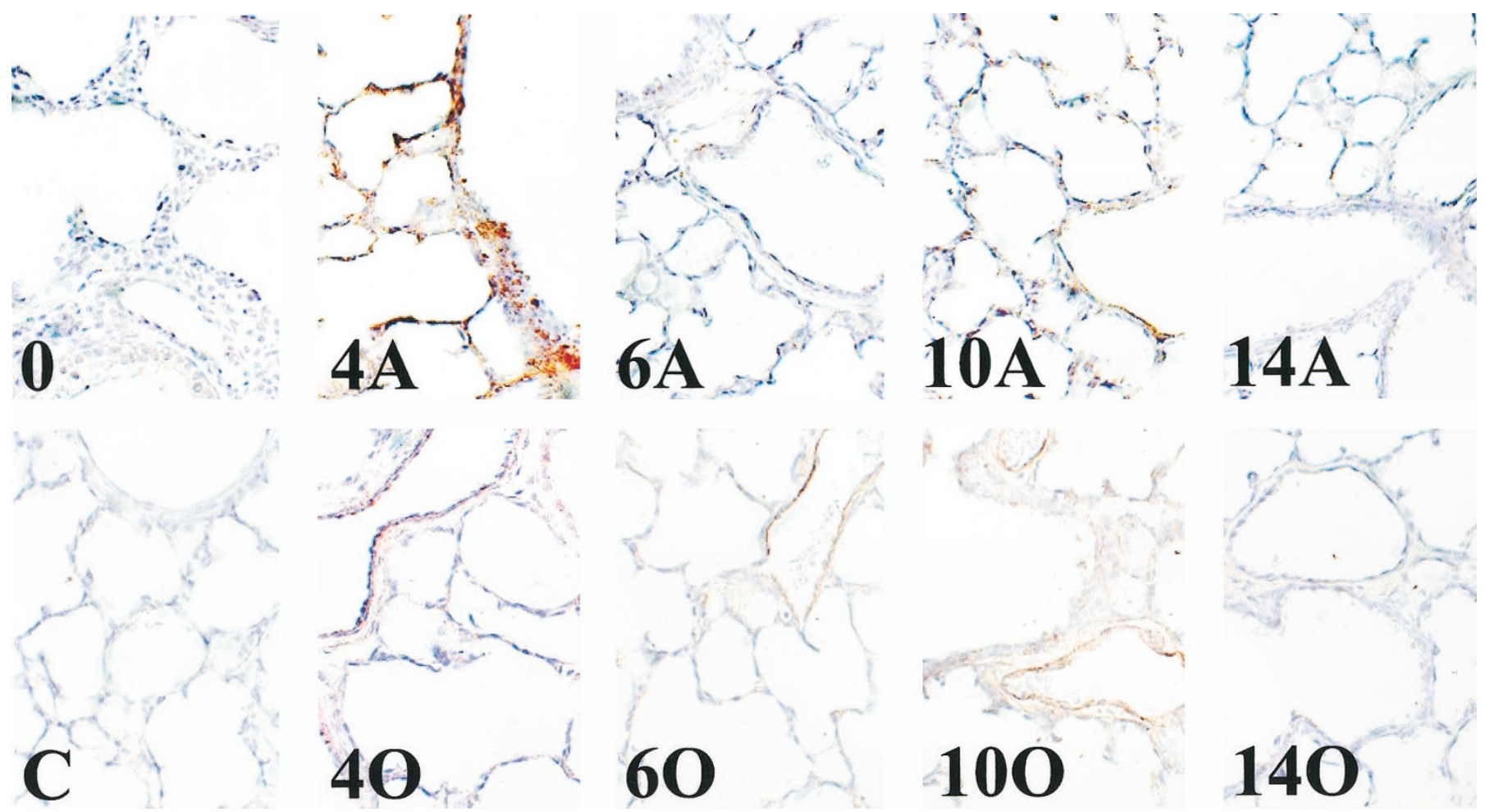

Figure 3. Immunohistochemistry for PDGF-BB. Lung tissue was studied at birth (0), at 4, 6, 10, and $14 \mathrm{~d}$ in air $(4 \mathrm{~A}, 6 \mathrm{~A}, 10 \mathrm{~A}, 14 \mathrm{~A})$ or at 4, 6, 10, and $14 \mathrm{~d}$ in $60 \% \mathrm{O}_{2}(4 \mathrm{O}, 6 \mathrm{O}, 10 \mathrm{O}, 14 \mathrm{O})$. Control sections $(C)$, from which the primary antibody had been omitted, showed no immunoreactivity. Immunoreactive PDGF-BB (brown stain) was not detected at birth, but was present at $4 \mathrm{~d}$ in air in airway $(a)$ and alveolar epithelium (arrowheads), with only minimal immunoreactivity thereafter. In the lungs of $60 \% \mathrm{O}_{2}$-exposed animals, PDGF-BB immunoreactivity was reduced at $4 \mathrm{~d}$, but was sustained thereafter being most evident in small vessel $(v)$ endothelial cells and both airway and alveolar epithelial cells (arrowheads) at 6 and 10 d. By 14 d, the PDGF-BB immunoreactivity in the lungs of $60 \% \mathrm{O}_{2}$-exposed animals was reduced to minimal perivascular staining. Original magnification for all panels $\times 250$. 

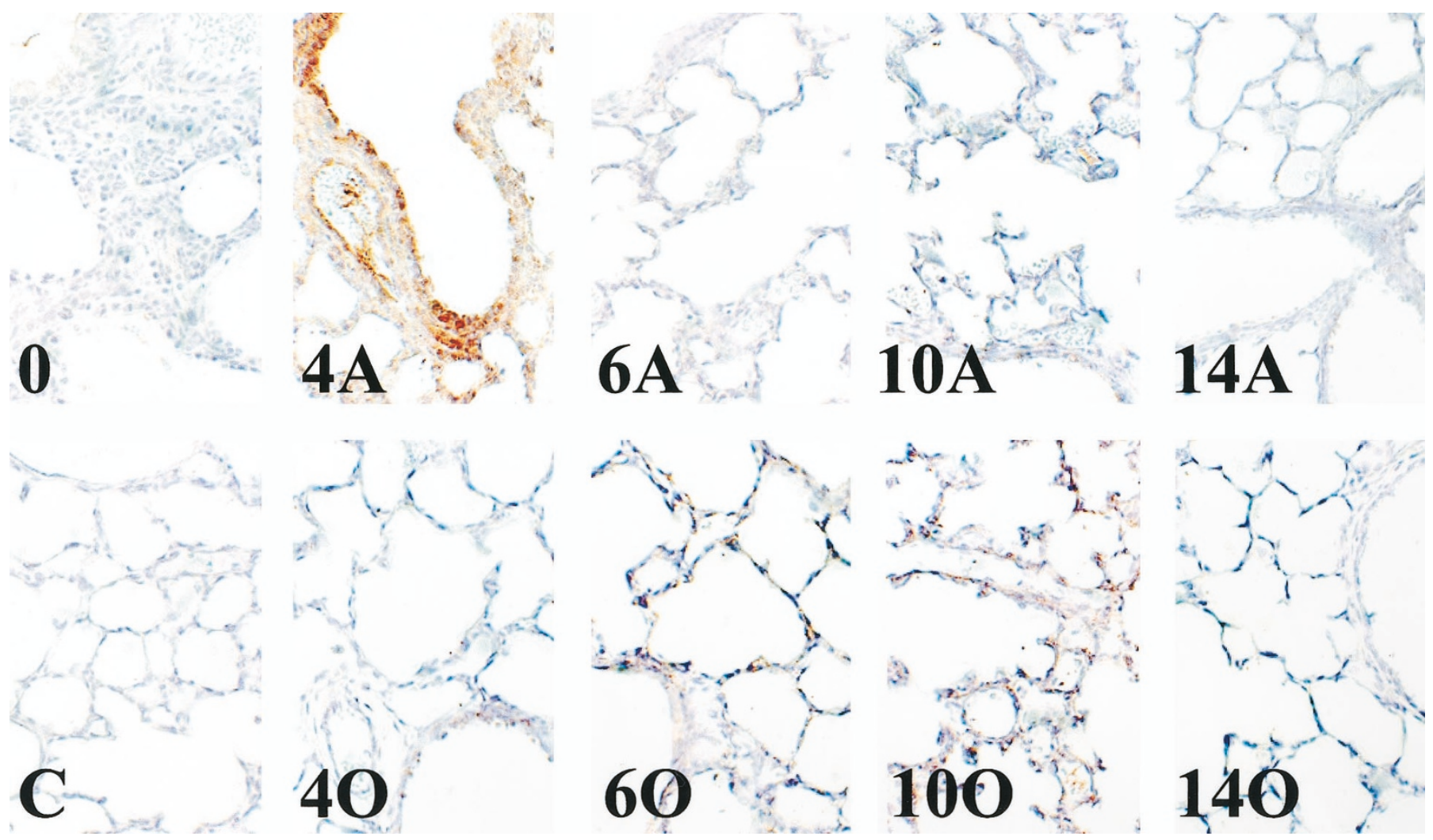

Figure 4. Immunohistochemistry for PDGF-AA. Lung tissue was studied at birth (0), at 4, 6, 10, and $14 \mathrm{~d}$ in air (4A, 6A, 10A, 14A) or at 4, 6, 10, and 14 d in $60 \% \mathrm{O}_{2}(4 \mathrm{O}, 6 \mathrm{O}, 10 \mathrm{O}, 14 \mathrm{O})$. Control sections $(C)$, from which the primary antibody had been omitted, showed no immunoreactivity. Immunoreactive PDGF-AA (brown stain) was not detected at birth. At $4 \mathrm{~d}$ in air, immunoreactivity was maximal in airway $(a)$ epithelium and small vessel ( $v$ ) endothelium, but was also detectable in all other portions of the lung. Immunoreactive PDGF-AA was not detected at 6,10 , or $14 \mathrm{~d}$ in air. In the lungs of $60 \% \mathrm{O}_{2}$-exposed animals, PDGF-AA immunoreactivity was markedly reduced at $4 \mathrm{~d}$, being only minimally evident in airway $(a)$ epithelium, but was evident throughout the lung at 6 and $10 \mathrm{~d}$ and not detected at $14 \mathrm{~d}$. Original magnification for all panels $\times 250$.

differences $(p<0.05)$ between the air-exposed and $60 \%$ $\mathrm{O}_{2}$-exposed animals at $4,6,10$, and $14 \mathrm{~d}$. In situ hybridization findings at $6 \mathrm{~d}$ were consistent with findings from Northern analysis, with no detectable signal for PDGF-B mRNA in air (Fig. $2 A$ ) and extensive signals throughout the lung parenchyma after $6 \mathrm{~d}$ of exposure to $60 \% \mathrm{O}_{2}$ (Fig. $2 B$ ). Negligible pulmonary PDGF-BB immunoreactivity was evident at birth (Fig. 3). In air, immunoreactivity to PDGF-BB was evident in airway epithelium and alveolar epithelial cells at $4 \mathrm{~d}$, with a decline in immunoreactivity at $6 \mathrm{~d}$, a slight increase at $10 \mathrm{~d}$, and minimal immunoreactive PDGF-BB by $14 \mathrm{~d}$. In the lungs of $60 \% \mathrm{O}_{2}$-exposed animals, PDGF-BB immunoreactivity was reduced at $4 \mathrm{~d}$, relative to air-exposed control animals, but was sustained thereafter, being most evident in small vessel endothelial cells and both airway and alveolar epithelial cells at $6 \mathrm{~d}$ and $10 \mathrm{~d}$. By $14 \mathrm{~d}$, the PDGF-BB immunoreactivity in the lungs of $60 \% \mathrm{O}_{2}$-exposed animals was negligible.

Northern blot analyses of PDGF-A mRNA identified a single transcript of $1.7 \mathrm{~kb}$ (Fig. 1), consistent with previous observations in fetal rat lung (32). In contrast to the observations with PDGF-B mRNA, the steady state expression of PDGF-A chain mRNA was not different between the airexposed and $60 \% \mathrm{O}_{2}$-exposed animals at any time point, and only animals exposed to air for $6 \mathrm{~d}$ had expression significantly $(p<0.05)$ above that seen at birth (Fig. 1). No difference between air- and $60 \% \mathrm{O}_{2}$-exposed animals at $\mathrm{d} 6$ was evident by in situ hybridization, with signal detected in only occasional epithelial cells (Fig. 2, $C$ and $D$ ). Pulmonary PDGF-AA immunoreactivity shared many features with PDGF-BB, in that it was barely detectable at birth, but was abundant at $4 \mathrm{~d}$ and decreased thereafter in animals breathing air (Fig. 4). At d 4, immunoreactivity was maximal in airway epithelium and small vessel endothelium, but was also detectable in all other portions of the lung. In the lungs of $60 \% \mathrm{O}_{2}$-exposed animals, PDGF-AA immunoreactivity was markedly reduced at $4 \mathrm{~d}$, being only minimally evident in airway epithelium, but was evident throughout the lung at $6 \mathrm{~d}$ and $10 \mathrm{~d}$ and not detected at $14 \mathrm{~d}$.

Northern blot analyses of PDGF- $\beta$ R mRNA identified a single transcript of $5.3 \mathrm{~kb}$ (Fig. 1), consistent with previous observations in fetal rat lung (32). The steady state expression of PDGF- $\beta$ R mRNA did not differ from values at birth in either the air-exposed or $60 \% \mathrm{O}_{2}$-exposed animals at any time point (Fig. 1). There was, however, a significant $(p<0.05)$ increase in the $60 \% \mathrm{O}_{2}$-exposed animals relative to the air-exposed animals at $6 \mathrm{~d}$. PDGF- $\beta$ R could be immunolocalized throughout the lung at birth (Fig. 5). At $4 \mathrm{~d}$, immunoreactivity in the lungs of animals breathing air had become more localized, in particular to subendothelial perivascular regions and to airway and alveolar epithelium. There was a subsequent decline in immunoreactivity thereafter, such that PDGF- $\beta$ R was only evident on airway epithelial cells by $14 \mathrm{~d}$. The $60 \% \mathrm{O}_{2}$ - 

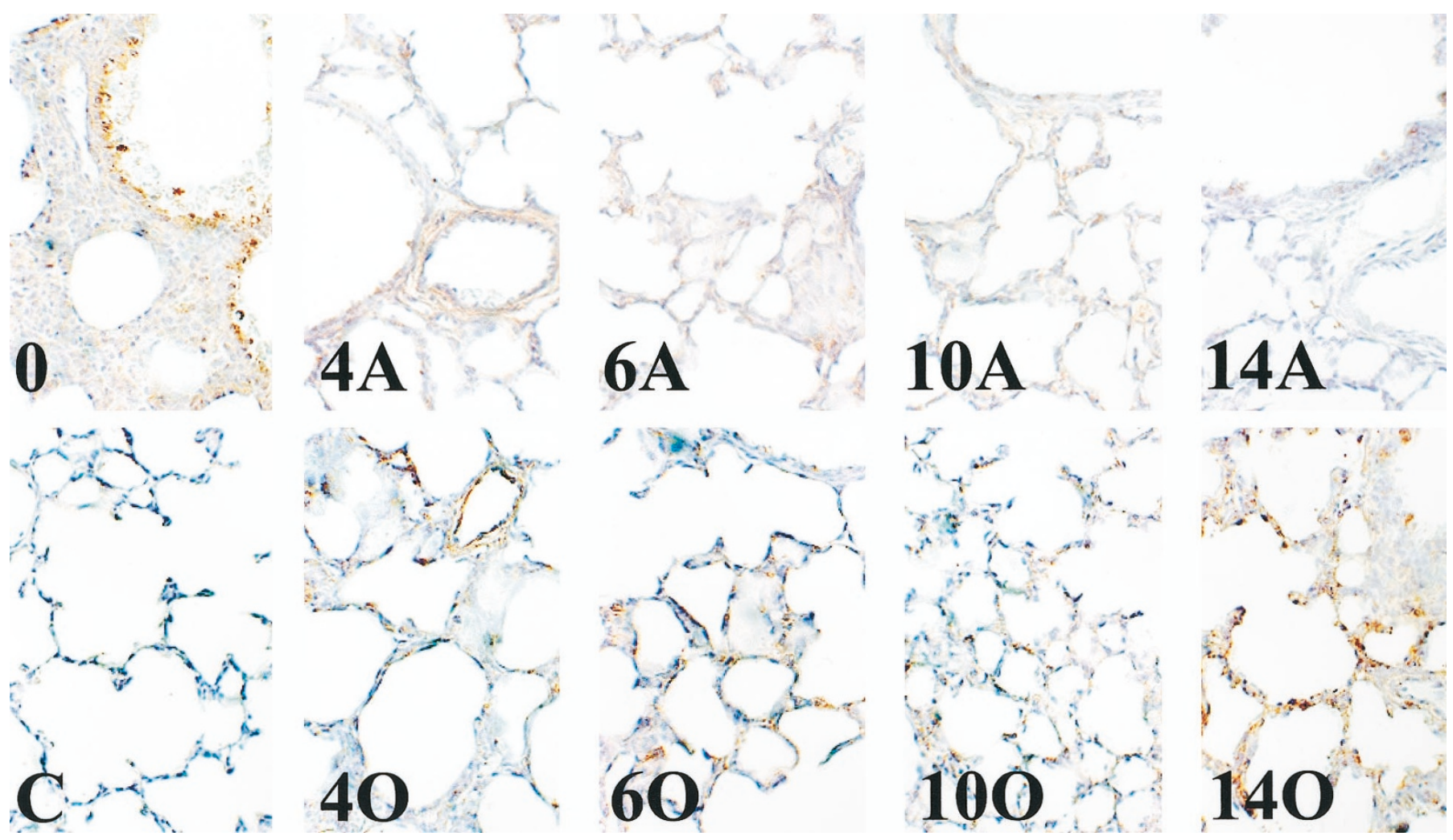

Figure 5. Immunohistochemistry for PDGF- $\beta$ R. Lung tissue was studied at birth (0), at 4, 6, 10, and $14 \mathrm{~d}$ in air $(4 \mathrm{~A}, 6 \mathrm{~A}, 10 \mathrm{~A}, 14 \mathrm{~A})$, or at 4, 6, 10, and $14 \mathrm{~d}$ in $60 \% \mathrm{O}_{2}(4 \mathrm{O}, 6 \mathrm{O}, 10 \mathrm{O}, 14 \mathrm{O})$. Control sections $(C)$, from which the primary antibody had been omitted, showed no immunoreactivity. Immunoreactive PDGF- $\beta$ R (brown stain) was evident throughout the lung at birth. At $4 \mathrm{~d}$, immunoreactivity in the lungs of animals breathing air had become more localized, in particular to subendothelial perivascular $(v)$ regions and to airway and alveolar epithelium (arrowheads). Immunoreactivity declined thereafter, such that the PDGF- $\beta$ R was only evident on airway $(a)$ epithelial cells by $14 \mathrm{~d}$. The $60 \% \mathrm{O}_{2}$-exposed animals had a similar distribution of the PDGF- $\beta \mathrm{R}$ at 4 , 6 , and $10 \mathrm{~d}$, but with a reduced staining intensity. After a 14-d exposure to $60 \% \mathrm{O}_{2}$, immunoreactive PDGF- $\beta \mathrm{R}$ was widely distributed throughout the lung parenchyma, particularly in areas of tissue thickening. Original magnification for all panels $\times 250$.

exposed animals has a similar distribution of PDGF- $\beta$ R at 4,6 , and $10 \mathrm{~d}$. A distinctly different pattern was observed after a 14 -d exposure to $60 \% \mathrm{O}_{2}$, with PDGF- $\beta \mathrm{R}$ being widely distributed throughout the lung parenchyma, particularly in areas of tissue thickening.

Northern blot analyses of PDGF- $\alpha$ R mRNA identified a single transcript of $6.5 \mathrm{~kb}$ (Fig. 1), consistent with observations in rat carotid artery (33). The abundance of PDGF- $\alpha \mathrm{R}$ mRNA was greatest at birth (Fig. 1), with a significant $(p<0.05)$ decline at all subsequent time points in air. In $60 \% \mathrm{O}_{2}$, there was a lesser postnatal decline that was only significant $(p<$ $0.05)$ at $10 \mathrm{~d}$ and $14 \mathrm{~d}$. A significant $(p<0.05)$ difference between groups was only found at $6 \mathrm{~d}$. Immunohistochemistry (Fig. 6) revealed the widespread presence of pulmonary PDGF- $\alpha \mathrm{R}$ at birth, which became more localized to airway epithelium by $4 \mathrm{~d}$ in air. Staining was reduced by $6 \mathrm{~d}$ in air-exposed animals, was in airway epithelial cells at $10 \mathrm{~d}$, and was in subendothelial perivascular tissue at $14 \mathrm{~d}$. In $60 \%$ $\mathrm{O}_{2}$-exposed animals, the intensity of staining was reduced at $4 \mathrm{~d}$, absent at $6 \mathrm{~d}$ and $10 \mathrm{~d}$, and had reappeared in airway epithelium at $14 \mathrm{~d}$. Compared with control lungs exposed to air for 4 (Fig. 7A) or $7 \mathrm{~d}$ (Fig. 7C), expression of $\alpha$-smooth muscle actin was decreased, as assessed by immunohistochemistry, in lung tissue of pups exposed to $60 \% \mathrm{O}_{2}$ for 4 (Fig. $7 B$ ) and $7 \mathrm{~d}$ (Fig. 7D).
To determine whether the expression of PDGF-BB in the air-exposed neonatal rat lung was causally related to early postnatal lung growth, two interventions designed to bind the PDGF-BB ligand and inhibit its binding to its natural PDGF $\beta$-receptor were used. Firstly, pups were injected intraperitoneally with either a neutralizing goat antibody to PDGF-BB, or a control rabbit $\operatorname{IgG}$, on $\mathrm{d} 4$ and $\mathrm{d}$ 5. Fluorescent detection of the goat antibody confirmed that it was evenly distributed throughout the lung tissue (Fig. 8, $A$ and $C$ ). Nonspecific fluorescence was not a contributing factor, in that no significant fluorescence was detected following injection of the rabbit antibody (Fig. 8, $B$ and $D$ ). Pups injected with a nonspecific goat antibody had normal PDGF-BB immunoreactivity (Fig. 9, $A$ and $B$ ), whereas there was a loss of PDGF-BB immunoreactivity (Fig. 9, $C$ and $D$ ) in the lungs of pups that received the PDGF-BB neutralizing antibody. We assume that binding of PDGF-BB to the neutralizing antibody masked sites on the PDGF-BB molecule necessary for immunoreactivity. Pups receiving intraperitoneal neutralizing antibodies to PDGF-BB on $\mathrm{d} 4$ and $\mathrm{d} 5$ had a significantly reduced $(p<0.05)$ lung DNA synthesis on $\mathrm{d} 6$, as assessed by $\left[{ }^{3} \mathrm{H}\right]$ thymidine incorporation into DNA (Fig. 10A). Injection of isotype control IgG had no significant independent effect $(p>0.05)$ on DNA synthesis (data not shown). Secondly, intraperitoneal injection of a truncated soluble PDGF $\beta$-receptor on d 2 also significantly inhib- 

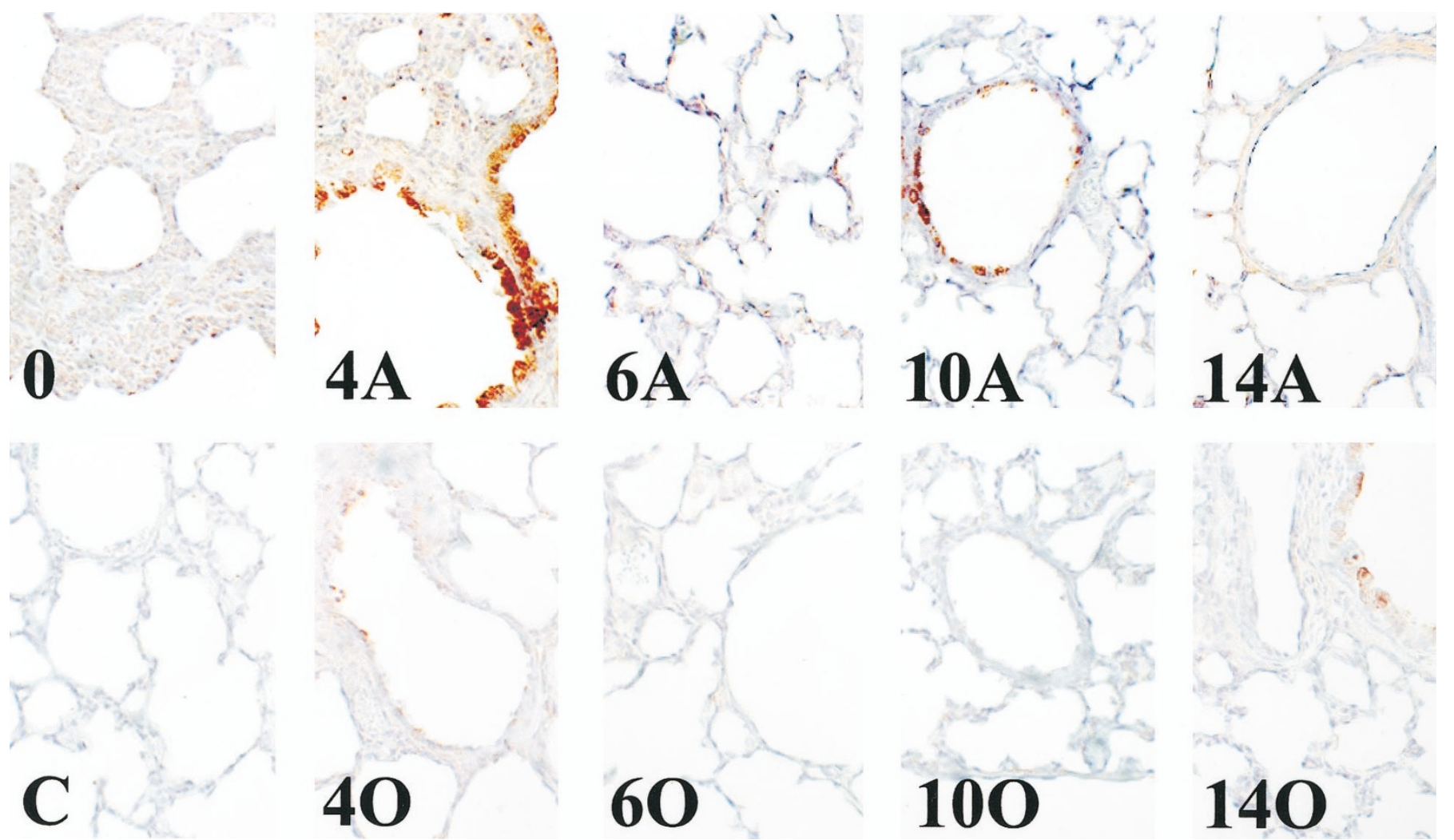

Figure 6. Immunohistochemistry for PDGF- $\alpha$ R. Lung tissue was studied at birth (0), at 4, 6, 10, and $14 \mathrm{~d}$ in air (4A, 6A, 10A, 14A) or at 4, 6, 10, and 14 d in $60 \% \mathrm{O}_{2}(4 \mathrm{O}, 6 \mathrm{O}, 10 \mathrm{O}, 14 \mathrm{O})$. Control sections $(C)$, from which the primary antibody had been omitted, showed no immunoreactivity. Immunoreactive PDGF- $\alpha$ R (brown stain) was evident throughout the lung at birth, and became more localized to airway (a) epithelium by $4 \mathrm{~d}$ in air. Staining was virtually undetectable by $6 \mathrm{~d}$ in air-exposed animals, was found in airway $(a)$ epithelial cells at $10 \mathrm{~d}$, and was found in subendothelial perivascular tissue at $14 \mathrm{~d}$. In $60 \%$ $\mathrm{O}_{2}$-exposed animals, the intensity of staining was reduced at $4 \mathrm{~d}$, absent at 6 and $10 \mathrm{~d}$, and had reappeared in airway $(a)$ epithelium at $14 \mathrm{~d}$. Original magnification for all panels $\times 250$.
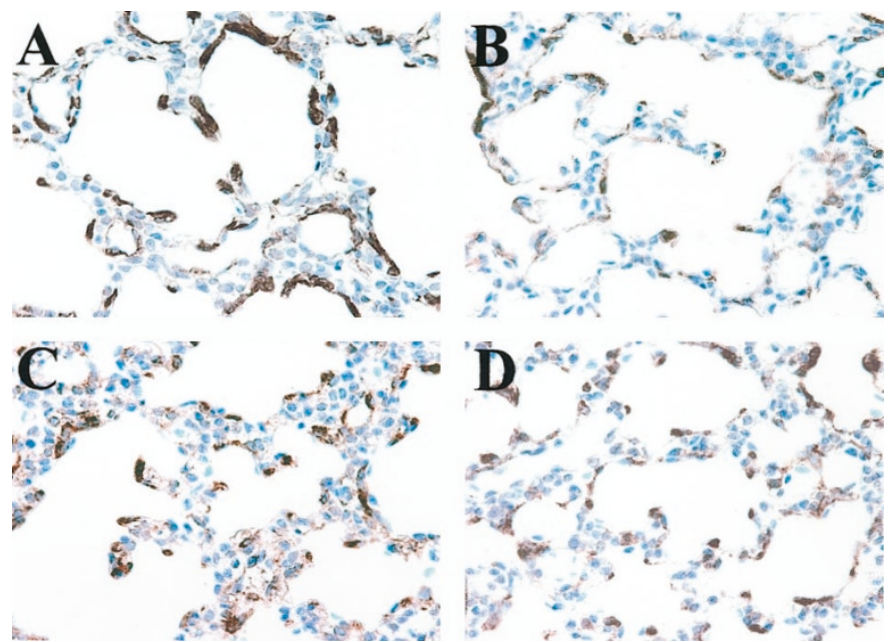

Figure 7. Immunohistochemistry for $\alpha$-smooth muscle actin. Lung tissue was studied at $4 \mathrm{~d}(A, B)$ and $7 \mathrm{~d}(C, D)$ of life following exposure to air $(A, C)$ or $60 \% \mathrm{O}_{2}(B, D)$. A decrease in immunoreactive $\alpha$-smooth muscle actin was evident in the lung tissue of pups exposed to $60 \% \mathrm{O}_{2}$ for 4 and $7 \mathrm{~d}$, relative to control animals in air. Original magnification for all panels $\times 320$.

ited $(p<0.05)$ lung DNA synthesis on $\mathrm{d} 4$, as assessed by $\left[{ }^{3} \mathrm{H}\right]$ thymidine incorporation into DNA (Fig. 10B).

\section{DISCUSSION}

A number of polypeptide growth factors, including PDGF (32), basic fibroblast growth factor (34), epidermal growth

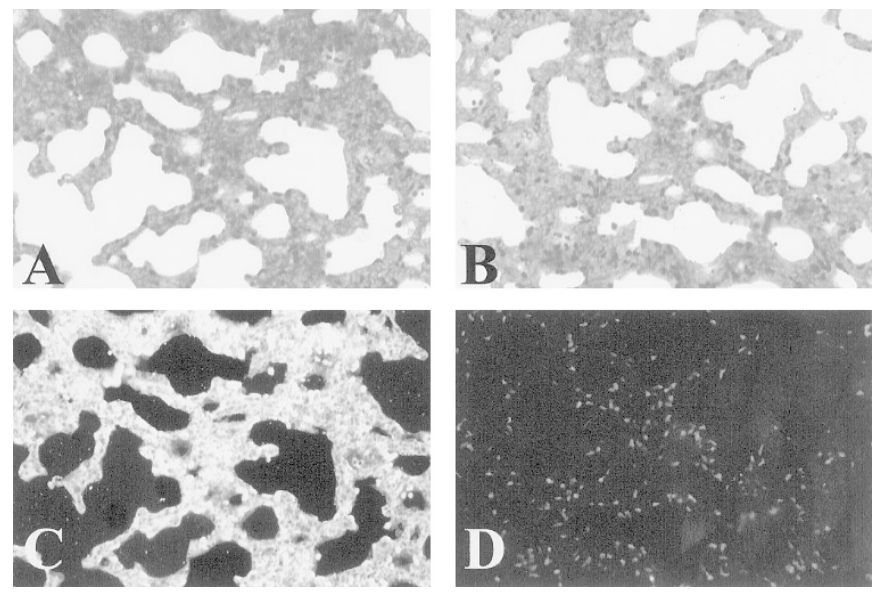

Figure 8. Localization of goat anti-human PDGF-BB to the lung, following intraperitoneal injection on $\mathrm{d} 4$ of life $(A, C)$, by fluorescence immunohistochemistry using FITC-conjugated rabbit anti-goat IgG on d 5 of life. Control pups received a nonspecific rabbit $\operatorname{IgG}(B, D)$. Marked fluorescence was evident in the lungs of pups receiving the goat antibody $(C)$, but not those receiving rabbit antibody $(D)$, by intraperitoneal injection. Light micrographs of the same fields are shown for comparison $(A, B)$. Original magnification for all panels $\times 250$.

factor (35), IGF (36), transforming growth factors $\beta 1-3$ (37, 38 ), and keratinocyte growth factor (39) are believed to play a role in the rapid cellular hyperplasias that occur during fetal lung development. However, much less information is avail- 


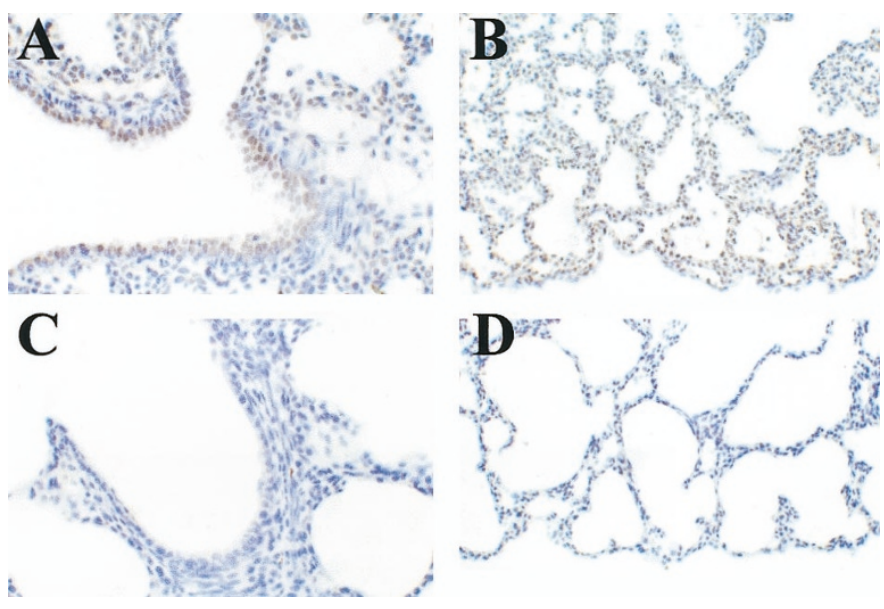

Figure 9. Loss of lung PDGF-BB immunoreactivity in animals receiving intraperitoneal goat anti-human PDGF-BB IgG. Normal immunoreactivity was evident in the lungs of animals receiving nonspecific goat $\operatorname{IgG}(A, B)$, but was lost in those animals receiving goat anti-human PDGF-BB $\operatorname{IgG}(C, D)$. Original magnifications $\times 400(A, C)$ or $\times 250(B, D)$.

able about the role of these factors in the pneumocyte, fibroblast, and endothelial cell population changes that occur during normal postnatal lung growth or after lung injury. Perhaps the best evidence available for the involvement of any one growth factor in normal postnatal lung growth is for the PDGF-AA isoform. PDGF-A knockout mice that survive beyond birth develop postnatal lung emphysema, secondary to a failure of alveogenesis attributed to a lack of alveolar myofibroblast differentiation and spreading (40). PDGF-AA can bind to both PDGF- $\alpha$ R and $-\beta R$, whereas PDGF-BB can only bind to PDGF- $\beta$ R (41). We (5), and others (4), in previous studies of hyperoxic lung injury in adult animal models have demonstrated an association of increased expression of PDGF-B chain and its receptor genes to areas of cellular hyperplasias within the injured lung. We have also shown the presence of PDGF and its receptors (17) on type II pneumocytes in vivo, and shown increased expression of their mRNAs when fetal rat lung epithelial cells are exposed to $50 \% \mathrm{O}_{2}$ in vitro (42). PDGF-BB stimulates DNA synthesis in both fetal rat lung epithelial cells (18) and microvascular epithelial cells (43). Taken together, these studies formed the basis for investigating the expression of PDGF and its receptors in the normal growth of postnatal rat lung and in the neonatal rat pup model of hyperoxic lung injury.

The $60 \% \mathrm{O}_{2}$-exposed neonatal rat lung has emphysematous areas of reduced cell proliferation (11), reminiscent of the changes seen in the lungs of PDGF-A knockout mice (40). We therefore hypothesized: (a) that the expression of PDGFrelated genes would show a temporal pattern of expression consistent with their having a role in normal postnatal lung growth and (b) that exposure to $60 \% \mathrm{O}_{2}$ would result in a reduced steady state mRNA abundance and an altered spatial pattern of PDGF-related gene expression analogous to that which we have previously reported for IGF-I and the IGF-IR (11).

In those animals breathing room air, immunoreactive PDGF$\mathrm{AA},-\mathrm{BB}$, and $-\alpha \mathrm{R}$, and PDGF- $\beta \mathrm{R}$ were maximal at $\mathrm{d} 4$ after birth. This is the time point, in the neonatal rat, at which secondary septation commences (44). The peak expression of these ligands showed a poor correlation with the steady state expression of their respective mRNA. Either a preceding peak of expression had occurred before $\mathrm{d} 4$ of life, or the postnatal expression of these ligands is not transcriptionally regulated. After day 4 , tissue expression of PDGF-BB and - $\alpha$ R correlated with changes in their respective mRNA, whereas PDGF-AA and $-\beta R$ continued to show no correlation. The finding that PDGF-AA tissue expression peaks at $\mathrm{d} 4$ is consistent with a critical role for PDGF-AA, acting through either the PDGF- $\alpha$ R or $-\beta \mathrm{R}$, to regulate secondary septation as suggested by studies in knockout mice (40), presumably through an effect on the alveolar myofibroblast. The presence of PDGF-BB in distal fetal lung cells, and the known mitogenic response of fetal and neonatal pneumocytes to PDGF-BB, suggests that PDGF-BB may be an autocrine competence growth factor acting through the PDGF- $\beta \mathrm{R}$ for normal type II pneumocyte proliferation
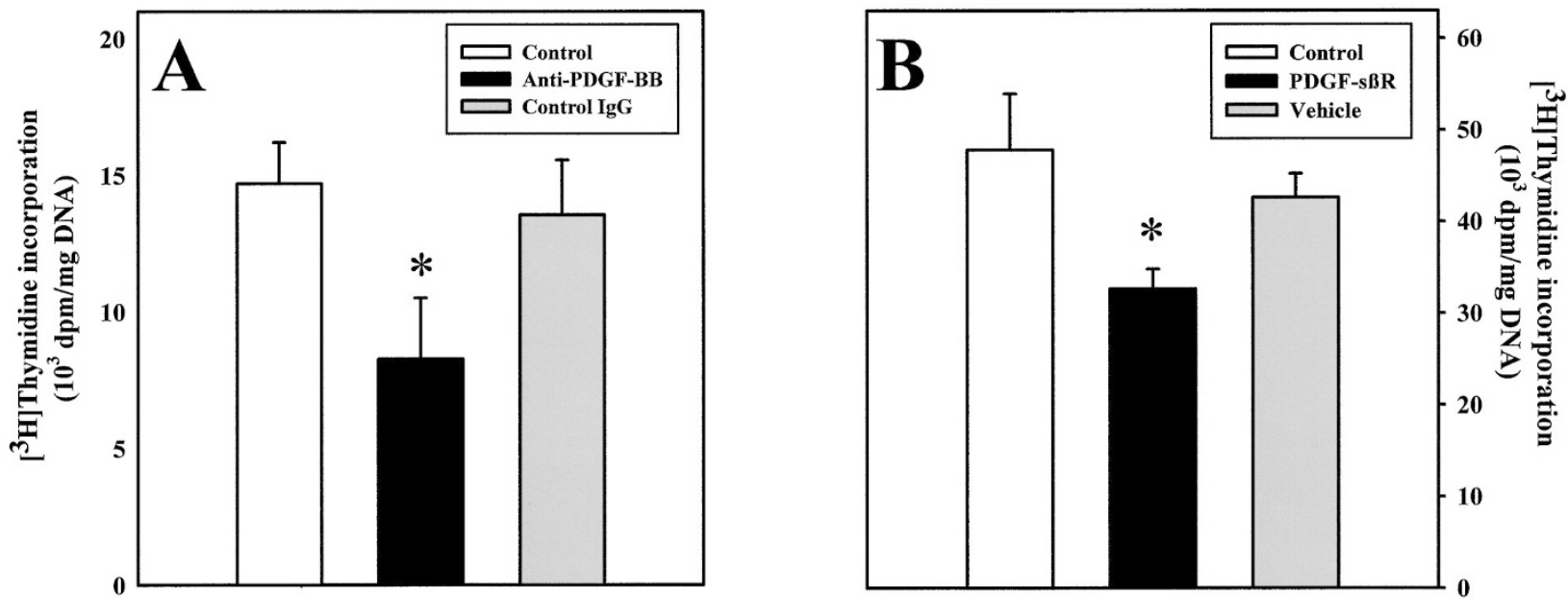

Figure 10. (A) Pups that had received intraperitoneal goat anti-human PDGF-BB IgG on $\mathrm{d} 4$ and $\mathrm{d} 5$ of life had a significantly reduced $\left[{ }^{3} \mathrm{H}\right]$ thymidine incorporation into lung DNA on d 6 of life (black bar), compared with animals that received nonspecific goat IgG (white bar) or uninjected control animals (shaded bar). (B) Pups that had received intraperitoneal truncated soluble PDGF $\beta$-receptor on $\mathrm{d} 2$ of life also had a significantly reduced $\left[{ }^{3} \mathrm{H}\right]$ thymidine incorporation into lung DNA on d 4 of life (black bar), compared with animals that received vehicle alone (white bar), or uninjected control animals (shaded bar). All data points represent the mean \pm SEM for 4 animals. ${ }^{*} p<0.05$. 
during normal postnatal lung growth in the rat. The peak of PDGF-BB expression at $\mathrm{d} 4$ may indicate a role for PDGF-BB in pneumocyte hyperplasia accompanying secondary septation. That PDGF-BB is indeed a critical growth factor in early postnatal lung growth is supported by our observation that both neutralizing antibodies to PDGF-BB and a truncated soluble PDGF $\beta$-receptor cause a significant reduction of DNA synthesis in the first week of life. A complete inhibition of DNA synthesis using either approach would be unlikely, in that not all cell types will be responsive to PDGF-BB and that PDGF-AA can act through the PDGF- $\beta$ R to facilitate proliferation (41). The functional significance of PDGF-BB and $-\beta R$ on airway epithelium of the air-exposed lung is presumably not related to cell division, in that airway formation is completed in early fetal life, but could be related to matrix deposition (41).

In the postnatal lungs of animals breathing $60 \% \mathrm{O}_{2}$, expression of PDGF-A mRNA was unchanged after birth, while the appearance of PDGF-AA immunoreactivity was dampened and delayed. This finding is again consistent with a critical role for PDGF-AA in normal secondary septation in that both the PDGF-AA knockout mouse (40) and the $60 \% \mathrm{O}_{2}$-exposed rat (11) have similar emphysematous peripheral air sacs. Pups exposed to $60 \% \mathrm{O}_{2}$ had reduced $\alpha$-smooth muscle actin immunoreactivity consistent with delayed myofibroblast differentiation, as observed in the PDGF-AA knockout mouse (40). The increased steady state expression of PDGF- $\alpha \mathrm{R}$ mRNA correlated poorly with PDGF- $\alpha$ R immunoreactivity, which showed a pattern similar to that seen with PDGF-AA, being generally decreased and delayed. Neither PDGF-AA nor PDGF- $\alpha$ R were specifically localized to areas of parenchymal thickening, suggesting that PDGF-AA acting through the PDGF- $\alpha$ R does not contribute to the cell proliferation observed at these sites. Following exposure to hyperoxia, the observed changes in PDGF-B and PDGF- $\beta$ R mRNA were somewhat more consistent with changes in the abundance of immunoreactive PDGF-BB and PDGF- $\beta$ R than was the case for the air-breathing group. The increase in immunoreactive PDGF$\beta R$, seen at d 14 in $60 \% \mathrm{O}_{2}$-exposed lung tissue, in areas of parenchymal thickening was consistent with the pattern previously reported with IGF-IR (11).

Taken together, these data are consistent with a critical role for PDGF-AA in secondary septation events occurring early in postnatal life, acting either through the PDGF- $\alpha \mathrm{R}$ or $-\beta \mathrm{R}$, and with PDGF-BB acting through the PDGF- $\beta$ R, as an autocrine growth factor in normal postnatal pneumocyte growth. Expression of the PDGF ligands and receptors is depressed and delayed in the $60 \% \mathrm{O}_{2}$-exposed lung, which may account, at least in part, for the emphysematous appearance of air spaces observed with this exposure protocol (11). In those areas of parenchymal thickening seen after a $14-\mathrm{d}$ exposure to $60 \% \mathrm{O}_{2}$, in which active cell division is present (11), PDGF- $\beta$ R immunoreactivity is markedly enhanced and widely distributed, suggesting that under these conditions PDGF- $\beta \mathrm{R}$ is also present on fibroblasts and endothelial cells. PDGF-BB is well recognized as a growth and chemotactic factor for mature lung fibroblasts (45), and is also a growth factor for fetal lung endothelial cells (43). That IGF-IR (11) and PDGF- $\beta$ R both localize to areas of parenchymal thickening suggests that
PDGF-BB and IGF-I may be acting as competence and progression factors, respectively, on actively proliferating cells at these sites.

\section{REFERENCES}

1. Saugstad OD 1996 Mechanisms of tissue injury by oxygen radicals: implications for neonatal disease. Acta Paediatr 85:1-4

2. Edwards DK, Dyer WM, Northway WH 1977 Twelve years' experience with bronchopulmonary dysplasia. Pediatrics 59:839-846

3. Anonymous 1979 Recommendations of the Workshop on Bronchopulmonary Dysplasia. J Pediatr 95:920

4. Fabisiak JP, Evans JN, Kelley J 1989 Increased expression of PDGF-B (c-sis) mRNA lung precedes DNA synthesis and tissue repair during chronic hyperoxia. Am J Respir Cell Mol Biol 1:181-189

5. Han RNN, Buch S, Freeman BA, Post M, Tanswell AK 1992 Platelet-derived growth factor and growth-related genes in rat lung. II. Effect of exposure to $85 \% \mathrm{O}_{2}$. Am J Physiol 262:L140-L146

6. Buch S, Han RNN, Liu J, Moore A, Edelson JD, Freeman BA, Post M, Tanswell AK 1995 Basic fibroblast growth factor and growth factor receptor gene expression in 85\% $\mathrm{O}_{2}$-exposed rat lung. Am J Physiol 268:L455-L464

7. Han RNN, Han VKM, Buch B, Freeman BA, Post M, Tanswell AK 1996 Insulin-like growth factor-I and type I insulin-like growth factor receptor in $85 \% \mathrm{O}_{2}$-exposed rat lung. Am J Physiol 271:L139-L149

8. Margraf LR, Tomashefski JF, Bruce MC, Dahms BB 1991 Morphometric analysis of the lung in bronchopulmonary dysplasia. Am Rev Respir Dis 143:391-400

9. Rosan RC 1975 Hyaline membrane disease and a related spectrum of neonatal pneumopathies. Perspec Pediatr Pathol 2:15-60

10. Escobedo MB, Hilliard JL, Smith F, Meredith K, Walsh W, Johnson D, Coalson JJ, Kuehl TJ, Null DMJ, Robotham JL 1982 A baboon model of bronchopulmonary dysplasia. I. Clinical features. Exp Mol Pathol 37:323-334

11. Han RNN, Buch S, Young J, Christie NA, Frndova H, Lye SJ, Post M, Tanswell AK 1996 Changes in structure, mechanics, and insulin-like growth factor-related gene expression in the lungs of newborn rats exposed to air or $60 \% \mathrm{O}_{2}$. Pediatr Res 39:921-929

12. Veness-Meehan KA, Moats-Staats BM, Price WA, Stiles AD 1997 Re-emergence of a fetal pattern of insulin-like growth factor expression during hyperoxic rat lung injury. Am J Respir Cell Mol Biol 16:538-548

13. Warner BB, Stuart LA, Papes RA, Wispé JR 1998 Functional and pathological effects of prolonged hyperoxia in neonatal mice. Am J Physiol 275:L110-L117

14. Kelley J 1990 Cytokines of the lung. Am Rev Respir Dis 141:765-788

15. King RJ, Jones MB, Minoo P 1989 Regulation of lung cell proliferation by polypeptide growth factors. Am J Physiol 257:L23-L38

16. Souza P, Tanswell AK, Post M 1996 Different roles for PDGF $\alpha$ and $\beta$ receptors in embryonic lung development. Am J Respir Cell Mol Biol 15:551-562

17. Han RNN, Mawdsley C, Souza P, Tanswell K, Post M 1992 Platelet-derived growth factors and growth related genes in rat lung. III. Immuno-localization during development. Pediatr Res 31:323-329

18. Jassal DR, Han RNN, Caniggia I, Post M, Tanswell AK 1991 Growth of fetal rat lung epithelial cells in a defined serum-free medium. In Vitro Cell Dev Biol 27A:625-632

19. Caniggia I, Liu J, Han RNN, Buch S, Funa K, Tanswell K, Post M 1993 Fetal lung epithelial cells express receptors for platelet-derived growth factor. Am J Respir Cell Mol Biol 9:54-63

20. Tanswell AK, Buch S, Liu M, Post M 1999 Factors mediating cell growth in lung injury. In: Bland RD, Coalson J (eds) Chronic Lung Disease of Early Infancy. Dekker, New York, pp 493-534

21. Chomsczynski P, Sacchi N 1987 Single-step method of RNA isolation by acidguanidium-thiocyanate-phenol-chloroform extraction. Anal Biochem 162:156-159

22. Wang J, Souza P, Kuliszewski M, Tanswell AK, Post M 1994 Expression of surfactant proteins in embryonic rat lung. Am J Resp Cell Mol Biol 10:222-229

23. Betsholtz C, Johnsson A, Heldin CH, Westermark B, Lind P, Urdea MS, Eddy R, Shows TB, Philpott K, Mellor AL, Knott TJ, Scott J 1986 cDNA sequence and chromosomal localization of human platelet-derived growth factor A chain and its expression in tumour cell lines. Nature 320:695-699

24. Bornthorn DT, Sultan P, Collins T 1991 Structure of the murine $c$-sis proto-oncogene (Sis, PDGFB) encoding the B chain of platelet-derived growth factor. Genomics 10:287-292

25. Horowitz S, Shapiro DL, Finkelstein JN, Notter RH, Johnston CJ, Quible DJ 1990 Changes in gene expression in hyperoxia-induced neonatal lung injury. Am J Physiol 258:L107-L111

26. Hsu SM, Raine L, Fanger H 1981 Use of avidin-biotin-peroxidase complex (ABC) in immunoperoxidase techniques: a comparison between $\mathrm{ABC}$ and unlabelled antibody (PAP) procedures. J Histochem Cytochem 29:577-580

27. Buch S, Jassal D, Cannigia I, Edelson J, Han R, Liu J, Tanswell K, Post M 1994 Ontogeny and regulation of platelet-derived growth factor gene expression in distal fetal lung epithelial cells. Am J Respir Cell Mol Biol 11:251-261

28. Han RNN, Liu J, Tanswell AK, Post M 1993 Ontogeny of platelet-derived growth factor receptor in fetal rat lung. Microsc Res Tech 26:381-388

29. Chomczynski P, Mackey K, Drews R, Wilfinger W 1997 DNAzol: a reagent for the rapid isolation of genomic DNA. Biotechniques 22:550-553

30. West DC, Sattar A, Kumar S 1985 A simplified in situ solubilization procedure for the determination of DNA and cell number in tissue cultured mammalian cells. Anal Biochem 147:289-295

31. Snedecor GW, Cochran WG 1980 Statistical Methods. Iowa State University Press, Ames, Iowa, pp 215-295 
32. Buch S, Jones C, Sweezey N, Tanswell AK, Post M 1991 Platelet-derived growth factor and growth-related genes in rat lung. I. Developmental expression. Am J Respir Cell Mol Biol 5:371-376

33. Mayesky MW, Reidy MA, Bowen-Pope DF, Hart CE, Wilcox JN, Schwartz JM 1990 PDGF ligand and receptor gene expression during repair of arterial injury. J Cell Bio 111:2149-2158

34. Henke C, Fiegel V, Peterson M, Wick M, Knighton D, McCarthy J, Bitterman P 1991 Identification and partial characterization of angiogenesis bioactivity in the lower respiratory tract after acute lung injury. J Clin Invest 88:1386-1395

35. Johnson MD, Gray ME, Carpenter G, Pepinsky RB, Stahlman MT 1990 Ontogeny of epidermal growth factor receptor and lipocortin-1 in fetal and neonatal human lungs. Hum Pathol 21:182-191

36. Klempt M, Hutchins AM, Gluckman PD, Skinner SJM 1992 IGF binding protein-2 gene expression and the location of IGF-I and IGF-II in fetal rat lung. Development 115:765-772

37. Heine UI, Munoz EF, Flanders KC, Roberts AB, Sporn MB 1990 Colocalization of TGF-beta 1 and collagen I and III, fibronectin and glycosaminoglycans during lung branching morphogenesis. Development 109:29-36

38. Pelton RW, Saxena B, Jones M, Moses HL, Gold LI 1991 Immunohistochemical localization of TGF- $\beta 1$, TGF- $\beta 2$, and TGF- $\beta 3$ in the mouse embryo: expression patterns suggest multiple roles during embryonic development. J Cell Biol 115:10911105
39. Post M, Souza P, Liu J, Tseu I, Wang J, Kuliszewski M, Tanswell AK 1996 Keratinocyte growth factor and its receptor are involved in regulating early lung branching. Development 122:3107-3115

40. Lindahl P, Karlsson L, Hellstrom M, Gebre-Medhin S, Willetts K, Heath JK, Betsholtz C 1997 Alveogenesis failure in PDGF-A-deficient mice is coupled to lack of distal spreading of alveolar smooth muscle cell progenitors during lung development. Development 124:3943-3953

41. Heldin C-H 1992 Structural and functional studies on platelet-derived growth factor. EMBO J 11:4251-4259

42. Buch S, Moore A, Post M, Tanswell AK 1992 In vitro expression of the genes for platelet-derived growth factor and its receptors in fetal lung cells exposed to hyperoxia. Pediatr Res 31:303A(abstr)

43. Tanswell AK, Han RNN, Jassal D, Fraher LJ, Post M 1991 The response of small vessel endothelial cells from fetal rat lung to growth factors. J Dev Physiol 15:199209

44. Burri PH 1991 Postnatal development and growth. In: Crystal RG, West JB (eds) The Lung: Scientific Foundations. Raven Press, New York, pp 677-687

45. Clark JG, Madtes DK, Raghu G 1993 Effects of platelet-derived growth factor isoforms on human lung fibroblast proliferation and procollagen gene expression. Exp Lung Res 19:327-344 